\title{
Право на индивидуальную жалобу по Европейской конвенции о защите прав человека и основных свобод 1950 г.
}

Курдюков Д.Г.

Одной из наиболее важных особенностей Европейской конвенции о защите прав человека и основных свобод (далее по тексту - «Европейская конвенция» или «Конвенция») является ее международный контрольный механизм, с помощью которого обеспечивается соблюдение «обязательств, принятых на себя Высокими Договаривающимися Сторонами» (статья 19 Конвенции). Средством, которое приводит в действие контрольный механизм, является жалоба.

Конвенция предусматривает две категории жалоб:

- индивидуальные жалобы по статье 34 (статья 25 в старой редакции Койвенции);

- межгосударственные дела по статье 33 (статья 24 в старой редакции Конвенции).

Межгосударственные дела заранее предполагают определенное политическое решение в государстве-заявителе и, следовательно, применяются либо в случае сильного политического интереса, либо когда речь идет об особенно серьезной ситуации, связанной с нарушениями прав человека. Представляется маловероятным, что дела без подобных признаков будут рассмотрены как межгосударственные, но при этом следует учитывать, что всегда существует возможность у заинтересованных лиц подать индивидуальные жалобы, которые фактически и составляют основное количество дел, рассматриваемых конвенционными органами.

Индивидуальная жалоба основана на «индивидуальном элементе», и только жертва предполагаемого нарушения Конвенции может пользоваться правом на жалобу в этой форме. Как показывает практика, возможность подачи индивидуальной жалобы позволила в определенной степени «нейтрализовать» нежелание или неспособность государств-

\footnotetext{
- Курдюков Дмитрий Геннадьевич - кандидат юридических наук.
} 
участников пользоваться своим правом по статье 33 Конвенции'. Поэтому индивидуальная жалоба представляет собой необходимое средство достижения цели Конвенции по защите прав и свобод человека и является ключом к успеху конвенционной системы ${ }^{2}$.

Так же как и в случае с другими правами, существуют определенные обязанности, связанные с правом на индивидуальную жалобу, которые по своей природе имеют два аспекта. Прежде всего, конвенционный контрольный механизм приводится в движение после того, как выполняются все условия, связанные с подачей индивидуальной жалобы, предусмотренные Конвенцией. Европейский суд по правам человека (далее по тексту - «Европейский суд» или «Суд») не обладает компетенцией действовать по своей инициативе и рассматривать вопросы соблюдения прав человека в отдельной стране или регионе, пока не будет подана соответствующая жалоба. Во-вторых, судебный характер рассмотрения жалобы требует продолжающейся помощи со стороны заявителя в виде предоставления надлежащих доказательств и аргументов. Не допускается, что заявитель может просто подать жалобу о нарушении Конвенции на рассмотрение в Суд и затем ничего больше в этой связи не делать. Право на индивидуальную жалобу подразумевает, что заявитель, кроме предоставления доказательств и аргументов в поддержку своих утверждений о нарушении каких-либо прав и свобод, должен также строго следовать установленной процедуре рассмотрения дел в Суде.

При составлении текста Конвенции право на индивидуальную жалобу было одобрено не без определенных дискуссий ${ }^{3}$. На ранней стадии имели место существенные разногласия во мнениях между Консультативной Ассамблеей и Комитетом министров. Ассамблея хотела включить право на индивидуальную жалобу, которое могло бы осушествляться во всех случаях, в то время как с точки зрения Комитета это право должно было осуществляться только под контролем и с согла-

\footnotetext{
' См.: Лукьяниев Г.Е. Европейские стандарты в области прав человека. Теория и практика функционирования Европейской конвенции о защите прав человека и основных свобод. - М.: Звенья, 2000. - Глава III, параграф 3.2.

2 См. также: Krüger H.C. \& Norgaard C.A. The Right of Application. // Macdonald R.St.J., Matscher F. Petzold $H$. The European System for the Protection of Human Rights. - Kluwer, 1993. - P. 657.

${ }^{3}$ См. также: Frowein J.A. \& Peukert $W$. EuropäischeMenschenRechtsKonvention. EMRKKommentar. - N.P. Engel Verlag, 1996. - P. 528-529.
} 
сия заинтересованного правительства ${ }^{4}$. Некоторые не так далеко заходящие модели оказались также неприемлемыми для Комитета министров. Было предложено, например, включить в Конвенцию право на индивидуальную жалюбу на условиях, что государство могло бы наложить вето на рассмотрение Европейской комиссией по правам человека (далее по тексту - «Европейская комиссия» или «Комиссия») определенной жалобы. Право на вето в свою очередь должно было бы стать предметом коллективного контроля другими государствами с целью недопущения злоупотребления этим правом. Консультативная Ассамблея предложила также формулу, в соответствии с которой право на индивидуальную жалобу должно было быть инкорпорировано в Конвенцию, но государства могли бы исключить это право в отношении жалоб, направленных против них ${ }^{5}$. В конечном итоге был достигнут компромисс в том виде, в каком он был отражен в статье 25 старой редакции Конвенции: «Комиссия может получать петиции, направленные в адрес Генерального секретаря Совета Европы от любого лица, неправительственной организации или группы лиц, которые утверждают, что они являются жертвами нарушения одной из Договаривающихся Сторон их прав, изложенных в настоящей Конвенции, при условии, что Высокая Договаривающаяся Сторона, на которую подана жалоба, заявила, что она признает компетенцию Комиссии получать такие петиции» (первое предложение п.1 статьи 25$)^{6}$.

Европейская комиссия получила юридические полномочия принимать индивидуальные жалобы согласно статье 25 (статья 34 в новой редакции Конвенции) с 5 июля 1955 г. $^{7}$ В тот день было выполнено условие, предусмотренное в п. 4 этой статьи, о заявлении по крайней мере шестью Договаривающимися Сторонами об обязательности для них ее положений. Со вступлением в силу Протокола № 11 в Конвен-

${ }^{4}$ Van Dijk P. \& van Hoof G.J.H. Theory and Practice of the European Convention on Human Rights. - Kluwer, 1998. - P. 44.

' См. подробнее: Collected Edition of the «Travaux Préparatoires» of the European Convention of Human Rights. - The Hague, 1977. - Vol.14. - P.114.

${ }^{6}$ Об историческом развитии права на индивидуальную жалобу см.: Mikaelsen $L$. European Protection of Human Rights: the Practice and Procedure of the European Commission of Human Rights on the Admissibility of Applications from Individuals and States. - Sijthoff \& Noordhoff, 1980. - P. 20-24.

${ }^{7} \mathrm{CM}$. также: Stock-Taking of the European Convention on Human Rights, a Periodic Note on the Concrete Results Archieved under the Convention, the First Thirty Years: 1954 until 1984. - Council of Europe, 1984. - P. 1. 
цию были внесены изменения, и компетенция Европейского суда принимать индивидуальные жалобы стала обязательной.

Статья 25 старой редакции Конвенции явилась, без сомнения, самым прогрессивным положением Конвенции, несмотря на то, что изначально право на индивидуальную жалобу было факультативным и обращаться можно было не напрямую в Европейский суд, а в Европейскую комиссию по правам человека. Право на индивидуальную жалобу позволило конвенционным органам рассматривать гораздо большее число дел, чем в случае, если бы система основывалась исключительно на межгосударственных делах. Более того, это позволило гарантировать детальный анализ ситуаций с правами человека в различных государствах-участниках практически во всех областях государственной деятельности, включая области, отдаленные от политических обсуждений. Можно сказать, что рассмотрение индивидуальных жалоб фактически стало основой конвенционной системы ${ }^{8}$.

Кто может подать индивидуальную жалобу.

Каждый, кто находится под юрисдикцией одной из Договаривающихся Сторон и, как предполагается, является жертвой нарушения Конвенции данным государством-ответчиком, может подать индивидуальную жалобу. Исходя из смысла статьи 1 Конвенции ${ }^{9}$, гражданство заявителя не имеет значения и понятие "каждому» включает также граждан (лиц) других государств-участников, граждан (лиц) государств, которые не являются участниками Конвенции, и лиц без гражданства. Многие другие статьи Конвенции также содержат слово "каждому» ${ }^{10}$. При этом важным является то, что данное лицо находилось под юрисдикцией государства-ответчика в тот момент, когда нарушение предположительно имело место.

Теоретически круг потенциальных субъектов права на индивидуальную жалобу очень широк, но фактически он намного уже. Статья 34 Конвенции упоминает три категории заявителей: физические лица, неправительственные организации и группы частных лиц.

Что касается физических лиц, то Конвенция не содержит требований и не проводит разграничение, которое существует в законодатель-

${ }^{8}$ См.: Krüger H.C. \& Nørgaard C.A. Op. cit. - P. 661.

9 «Высокие Договаривающиеся Стороны обеспечивают каждому, находящемуся под их юрисдикцией права и свободы, определенные в Разделе I настоящей Конвенция». ${ }^{10}$ См. также: Delvaur $H$. The Notion of Victim under Article 25 of the European Convention on Human Rights. // Maier I. (ed.). Protection of Human Rights in Europe. Limits and Effects. - Heidelberg, 1982. - P. 37. 
стве большинства Договаривающихся Сторон, в отношении правоспособности и дееспособности физических лиц". Например, в нескольких делах было установлено, что несовершеннолетние имеют право подавать жалобы по собственной воле и быть представленными даже лицами, которые по национальному законодательству не являются их законными представителями ${ }^{12}$. То же самое применяется и к лицам, потерявшим правоспособность после помещения в психиатрическую больницу ${ }^{13}$.

Вне всяких сомнений, Конвенция не содержит каких-либо ограничений, основанных на «социальных критериях». Подача жалобы в Суд не влечет никаких процессуальных расходов, поскольку расходы, связанные с деятельностью Суда, несет Совет Европы (статья 50 «Расходы на содержание Суда» Европейской конвенции), что позволяет обращаться даже самым бедным. Кроме этого, если заявитель не располагает достаточными средствами для оплаты юридической помощи, связанной с ведением дела, то Суд может освободить его от полной или частичной оплаты соответствующих расходов ${ }^{14}$. В суммы, предназначенные для оплаты юридической помощи, могут быть включены не только вознаграждение представителей, но и расходы на проезд и проживание и другие необходимые расходы заявителя или назначенного представителя (п. 2 правила 94 Правил процедуры Суда).

Юридические лица не упоминаются в статье 34. Ясная отсылка к ним дана только в статье 1 Протокола № 1 к Конвенции («Зашита собственности»). Тем не менее, в системе статьи 34 Конвенции юридические лица появляются, исходя из концепции «неправительственной организации», и они могут подавать жалобы также и о нарушении других конвенционных прав в случае, если пользование данными правами не противоречит существу юридических лиц ${ }^{15}$. Не требует доказательства то, что они не могут ссылаться на некоторые права, например право на жизнь (статья 2 Конвенции), запрещение пыток (статья 3 Кон-

$"$ См.: Delvatux H. Op. cit. - P. 37.

${ }^{12}$ См. например: решение по делу Nielsen $v$ : Denmark от 28 ноября 1988 г. // Series A: Judgments and Decisions (Далее ло тексту - «Series A»). - 1989. - №144. - P. 8.

${ }_{13}$ См., например: решение по делу Herczegfalvy v. Austria or 24 сентября 1992 г. // Series A. - 1993. - № 244. - P. 8.

14 Правило 91 и правило 92 Регламента Европейского Суда по правам человека от 4 ноября 1998 г. «Правина процелуры Суда» (далее по тексту - «Правипа процедуры Суда»).

${ }^{15}$ При этом, однако, тот факт, что затрагиваются права работников юридического лица, не считается достагочным. 
венции), право на вступление в брак (статья 12 Конвенции). В отношении же некоторых других прав было косвенно или достаточно ясно признано, что они могут применяться в отношении юридических лиц ${ }^{16}$. Интересным примером является статья 9 («Свобода мысли, совести и религии»), где Европейская комиссия разграничила свободу совести и свободу религии в рассматриваемом контексте. Было признано, что право на свободу религии имеют не только физические лица, но таке и церкви ${ }^{17}$, в свою очередь юридические лица не обладают правом на свободу совести ${ }^{18}$.

Категория «неправительственные организации» может включать организации, которые по национальному праву не рассматриваются как юридические лиша, например определенные виды товариществ по законодательству некоторых Договариваюшихся Сторон. «Неправительственный» характер рассматриваемых организаций означает, что они не должны быть государственными организациями, которые участвуют в осуществлении государственной власти. Соответственно, муниципальные образования не могут подавать жалобы в Суд, даже в отношении их собственности или гражданских прав, а также если речь идет о самом что ни на есть прямом и откровенном нарушении закрепленных за ними полномочий.

Под группами частных лиц подразумеваются в основном объединения (обычно временные) двух или более лиц, утверждающие, что они являются жертвами нарушения Конвенции ${ }^{19}$. В том случае, если группы частных лиц не созданы надлежащим образом в соответствии с законодательством одной из Договаривающихся Сторон, то жалоба должна быть подписана всеми лицами, принадлежащими к группе. Следовательно, невозможно, например, для членов национального

${ }^{16}$ См., например: жалоба №8191/78, Rassemblement Jurassien v. Switzerland // Decisions and Reports of the European Commission of Human Rights (Далее по тексту - «D\&R»). 1980. - № 17. - P. 93; жалоба № 8440/70, Christians Against Racism and Fascism v. The United Kingdom // D\&R. - 1981. - № 21. - P. 138; решение по делу Autronic A.G. v. Switzerland oт 22 мая 1990 г. // Series A. - 1990. - № 178.

${ }_{17}$ См.: жалоба №8282/78, Church of Scientology v. Sweden // D\&R. - 1981. - № 21. P. 109.

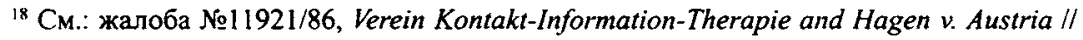
D\&R. - 1988. - № 57. - P. 81.

19 Первым делом такого рода было так называемое «Бельгийское лингвистическое дело" ("Belgian Linguistics Case»). См.: решение по делу Case "Relating to Certain Aspects of the Laws on the Use of Languages in Education in Belgium" v. Belgium or 9 февраля 1967 г. // Series A. - 1967. - № 5. 
меньшинства, которые хотят коллективно осуществить свои права, обратиться в конвенционные органы через представительный орган ${ }^{20}$. «Жертва».

Факт требования восстановления «своих прав» очень важен. Только те заявители, «которые утверждают, что явились жертвами нарушения» (статья 34 Конвенции) конвенционных прав, могут пользоваться правом подачи индивидуальной жалобы. Это подразумевает, что заявитель сам является жертвой предполагаемого нарушения Конвенции и, соответственно, жалобы, подаваемые третьими лицами или организациями, на которых не влияет данное нарушение, исключаются. Последние могут лишь представлять жертву или помогать ей. В соответствии с установившейся практикой Суда, слово «жертва) в контексте статьи 34 Конвенции означает лицо, которое напрямую затронуто рассматриваемым в деле действием или бездействием. К этому Суд, однако, обычно добавляет фразу: «Сушествование нарушения представляется возможным даже при отсутствии ущерба; ущерб имеет значение только в контексте статьи 41 Конвенции («Справедливая компенсация). - Д. К. $) »^{2 !}$.

Индивидуальный заявитель, в отличие от Договаривающихся Сторон, не может возражать против национального законодательства или каких-либо актов как таковых, его жалоба должна основываться на конкретном деле с прямыми для него последствиями. Обычно такое дело может возникнуть только в случае, когда нормативный или индивидуальный акт фактически применяется к заявителю и предположительно нарушает Конвенцию. Это объясняется тем, что в большинстве случаев законы осуществляют лишь общее регулирование и напрямую не могут определить исход отдельного дела. Для этого необходимо их применение исполнительным или судебным органом, «который применяет общие установления к обстоятельствам конкретного дела» 22 .

Таким образом, статья 34 не предоставляет индивидуальньм заявителям какой-либо возможности actio popularis (действие в общественном интересе - лат.) и не допускает также жалобы in abstracto (в абст-

${ }^{20}$ См: решение по делу $X$ v. Austria от 10 октября 1979 г. // D\&R. - 1980. - № 18. - P. 88.

"1 См. например: решение по делу Brumarescu v. Romania от 28 октября 1999 г. // HUDOC - Database of the Case-Law of the European Convention on Human Rights: wuwechr.coe.int Hudoc.htm (Далее по тексту - «HUDOC»).

2 Rogge $K$. The «Victim» requirement in Article 25 of the European Convention on Human Rights. // Matscher F. \& Petzold H. (eds.). Protecting Human Rights: The European Dimention. Studies in Honour of G.J. Wiarda. - Carl Heymanns Verlag KG, 1988. - P. 540. 
ракции - лат.) только потому, что заявители думают, что нормативноправовой или индивидуальный акт противоречит Конвенции. Поэтому «в принципе индивидуальному заявителю недостаточно утверждать, что просто существование закона нарушает его права по Конвенции; необходимо, чтобы этот закон был применен в ущерб ему» ${ }^{23}$.

В деле, где заявители утверждали, что они представляют «более одного миллиона человек в Северной Ирландии, которые имеют право голоса на выборах», Европейская комиссия, сославшись на actio popularis, напомнила, что предполагаемые нарушения Конвенции могут рассматриваться только в случае, если они затрагивают индивидуальные права заявителей ${ }^{24}$. Кроме того, в другом деле Комиссией было установлено, что тот факт, что профсоюзы рассматривают себя защитниками коллективньх интересов их членов, недостаточен для признания зтих организаций жертвами мер, наносяцих ущерб данным членам по смыслу статьи 25 (статьи 34 в новой редакции Конвенции) $)^{25}$.

Требование о том, чтобы заявителя лично затрагивало предполагаемое нарушение, было отмечено Комиссией с самого начала. Так, жалоба, в которой утверждалось, что Норвежское законодательство, касающееся abortus provocatus (незаконный аборт - лат.), находилось в противоречии с п. 1 статьи 2 Конвенции («Право на жизнь»), была признана жалобой in abstracto и отклонена, поскольку заявитель не утверждал, что он сам был жертвой этого законодательства, а подал жалобу «от имени родителей, которые без своего согласия или по незнанию ... лишались или будут лишаться потомков из-за abortus provocatus, и от имени тех, кто был забран такими операциями, - всех, кто не может или неспособен отстаивать свои интересы ${ }^{26}$.

Комиссия, однако, признавала приемлемыми индивидуальные жалобы, которые были частично абстрактного характера. Например, группа граждан Северной Ирландии жаловалась, с одной стороны, на то,

${ }^{23}$ Решение по делу Klass and Others v. The Federal Republic of Germany от 6 сентября 1978 r. // Series A. - 1979. № 28. P. 18.

${ }^{24}$ Жалоба No31699/96, Lindsay and Others v. The United Kingdom // HUDOC.

${ }_{25}^{25}$ Жалоба №1 5404/89, Purcell v. Ireland // D\&R. - 1991 . - № 70. - P. 262. Следует отметитъ, что профсоюзы, также как правозащитные и другие подобные организации, могут действовать лишь опосредованным образом, например, уговорить конкретное лицо или группу лиц, чьи права или свободы предполагаемо подверглись нарушению, подать индивидуальную жалобу в Европейский суд, а затем через участие в процедуре разбирательства способствовать данным жертвам нарушений.

${ }^{26}$ Жалоба № 867/60, X. v. Norway // Yearbook of the European Convention on Human Rights (Далее по тексту - «Yearbook»). - 1961. - № 4. - P. 274-276. 
что они были подвержены Британской Армией пыткам и бесчеловечному и унижающему достоинство обращению во время содержания под стражей, с другой стороны, одновременно они жаловались, что подобное обращение являлось частью систематической жестокости. Заявители просили Комиссию, inter alia, провести полное расследование как фактов, изложенных в жалобе, так и системы допросов, использовавшейся в то время войсками безопасности под контролем Соединенного Королевства в Северной Ирландии, с целью установления, не являлись ли подобные действия и существовавшая административная практика несовместимыми с Европейской конвенцией. В свою очередь британское правительство утверждало, что вторая часть жалобы была неприемлемой и ссылалось при этом на прецедентное право Комиссии в отношении абстрактных жалоб. Однако Комиссия признала, что «ни статья 25 (статья 34 новой редакции Конвенции. - Д.К.), ни другие положения в Конвенции, inter alia статья 27 (1) (b) (п. 2 (a) статьи 35 новой редакции Конвенции. - Д.К.), не мешают индивидуальному заявителю подавать жалобу в Комиссию в отношении утверждаемой административной практики, нарушающей Конвенцию, учитывая, что он предоставит prima facie доказательство подобной практики и то, что он является ее жертвой ${ }^{27}$.

Индивидуальная жалоба, следовательно, может затрагивать не только личный интерес заявителя, но также и публичный интерес, и поэтому процедура, берущая начало от индивидуальной жалобы, может предполагать определенный «объективный характер», присущий межгосударственным жалобам 28 . Таким образом, конвенционные органы заняли такую позицию, что на основании общей функции, предусмотренной в статье 19, по обеспечению соблюдения обязательств, принятых на себя Договаривающимися Сторонами, они обладают компетенцией рассматривать ex officio, в том числе и в случае индивидуальной жалобы, было или нет нарушение. Было установлено, что Комиссия (а в настоящее время Европейский суд) не должна ограничивать себя только исследованием нарушений, непосредственно предполагаемых заявителем ${ }^{29}$.

\footnotetext{
${ }^{27}$ Жалобы № 5577/72 и № 5583/72 (Joined), Donelly and Others v. The United Kingdom / / Yearbook. - 1973. № 16. P. 260.

${ }^{28}$ Об "объективном характере» межгосударственных жалоб см.: Van Dijk $P$. \& van Hoof G.J.H. Op. cit. - P. 40-41.

9 См., например: жалоба № 202/56, X v. Belgium // Yearbook. 1955-1957. P. 192.
} 
Другой, подразумеваемый из вышеизложенного, «объективный характер» проявил себя в позиции страсбургских органов в отношении тех заявителей, которые отказывались от своих жалоб либо более не проявляли интерес к делу. Здесь необходимо заметить, что в подобных случаях процедура рассмотрения не обязательно завершается, а может быть продолжена, если этого требует соблюдение прав человека, гарантированных Конвенцией и Протоколами к ней, что предусмотрено в п.l статьи 37. Например, в решении по делу Gericke v. The Federal Republic of Germany ${ }^{30}$ Комиссия установила, что «интересы, которым служит защита прав человека и основных свобод, гарантированных Конвенцией, распространяются дальше, чем индивидуальные интересы заинтересованных лиц; ... соответственно, отзыв жалобы и согласие с этим отвечающего правительства не может лишить Комиссию компетенции продолжить рассмотрение дела».

Для решения о приемлемости заявитель не должен доказывать, что он является жертвой предполагаемого нарушения. Статья 34 предусматривает, что заявителями могут быть лица, «которые утверждают, что явились жертвами». Однако это само по себе не означает, что просто утверждение заявителя о том, что он является жертвой, признается достаточным. Суд, решая вопрос о том, имело ли место предполагаемое нарушение и можно ли считать заявителя жертвой, основывается на фактах, предоставленных данным лицом, и фактах, выдвинутых государством-ответчиком, если таковые имеются. Если Суд находит, что заявитель не может быть признан жертвой, то жалоба объявляется «несовместимой с положениями Конвенции» и на основании п. 3 статьи 35 признается неприемлемой. С другой стороны, даже если заявитель не представляет на рассмотрение достаточно ясных фактов в отношении оспариваемого действия или бездействия, Суд, тем не менее, может рассмотреть данный вопрос и признать жалобу приемлемой, если он считает, что для этого имеются достаточные основания.

«Потенциальная жертва».

Европейская комиссия и Суд признали жертвами по смыслу статьи 34 (статья 25 в старой редакции Конвенции) категорию лиц, в отношении которых нельзя было с достоверностью установить, имело ли место нарушение их прав по Конвенции. Причиной этому явился тот факт, что заявители не могли знать, применялось ли к ним оспариваемое законодательство. Данный вопрос возник в деле Klass and Others v.

30 Жалоба № 2294/64 // Yearbook. - 1965. - № 8. - P. 314. 
The Federal Republic of Germany ${ }^{31}$. Судья, прокурор и три адвоката утверждали, что имело место нарушение властями тайны их переписки и телефонных разговоров. Предпринятые властями меры были тайными, поскольку данные лица не были проинформированы о них во всех случаях, а если и были, то только уже впоследствии. Комиссия, подчеркивая тайный характер мер, решила в достаточно краткой форме, что «учитывая особенности дела, заявители должны быть признаны жертвами по смыслу статьи 25 (статья 34 новой редакции Конвенции. - Д.К.)». Суд рассмотрел данный вопрос более детально ${ }^{32}$. Он констатировал, что статья 25 (статья 34 в новой редакции Конвенции) не предоставляет им что-то подобное actio popularis, и она не позволяет отдельным лицам подавать жалобу на закон in abstracto только потому, что они считают, что он нарушает Конвенцию. Однако принцип эффективности, в соответствии с практикой Суда, предполагает определенные исключения из этого правила. Этот принцип подразумевает, что процессуальные нормы Конвенции должны применяться таким образом, чтобы сделать действенной систему индивидуальных жалоб. В соответствии-с зтим Суд признал, что «лицо может при определенных условиях утверждать, что оно является жертвой нарушения в связи с самим существованием тайных мер или законодательством, допускающим такие тайные меры, без необходимости утверждать, что оно фактически подвергалось действию этих мер» ${ }^{33}$.

В рассматриваемом деле такие условия были, и Суд отметил, что оспариваемое законодательство вводило систему наблюдения, согласно которой потенциально у всех жителей Германии могли быть проверены письма, почтовые отправления и телефонные разговоры, о чем они могли бы не быть поставлены в известность, если бы не имела места какая-либо утечка информации или не было бы направлено определенное уведомление.

Из этого можно сделать вывод, что в случае существования тайных мер (основанных или нет на законодательстве) требование о призна-

\footnotetext{
${ }^{31}$ Жалоба № 5029/71, Klass and Others v. The Federal Republic of Germany // Yearbook. 1974. № 17. Р. 178.

${ }^{32}$ Решение Суда от 6 сентября 1978 г. // Европейский Суд по правам человека. Избранные решения: В 2 т. - М.: Издательство НОРМА, 2000. - Т. 1. - С. 168.

${ }^{33}$ Решение Суда по делу Klass and Others v. The Federal Republic of Germany от 6 сентября 1978 г. // Европейский Суд по правам человека. Избранные решения: В 2 т. М.: Издательство НОРМА, 2000. - Т. 1. - С. 171.
} 
нии заявителя жертвой по статье 34 может выполняться уже в случае, когда он является потенциальной жертвой («Potential Victim») $)^{34}$.

На позицию Суда в деле Klass and Others v. The Federal Republic of Germany ссылались заявители в другом деле, где две матери от имени своих детей подали жалобу о нарушении статьи 3 Конвенции («Запрещение пыток») на том основании, что в школах Шотландии, которые посещали их дети, применялась система телесных наказаний. Комиссия установила, что в этом деле не было прямой аналогии с делом Klass and Others $v$. The Federal Republic of Germany, но она сослалась на критерий эффективности, на который опирался Суд в этом деле. Таким образом, Комиссия решила, что для того чтобы признать индивидов жертвами по статье 25 (статья 34 новой редакции Конвенции), они «должны убедить Комиссию, что они подвергаются опасности понести ущерб от того конкретного случая, который они хотят передать на ее рассмотрение ${ }^{35}$.

Таким образом, просто факт быть подверженным опасности был признан достаточным для признания заявителя «жертвой». По мнению конвенционных органов, толкование статьи 25 (статья 34 новой редакции Конвенции) было бы слишком ограничительным, если бы требовалось предоставление фактов о том, что к детям действительно применялись телесные наказания. Следовательно, дети были признаны жертвами, поскольку им «мог быть нанесен ущерб сушествованием физического насилия вокрут них и угрозой потенциального применения в отношении них самого телесного наказания» ${ }^{36}$.

Следовательно, статья 34 Конвенции предоставляет лицу право утверждать, что нормативно-правовой акт нарушает его права, если оно подвергается риску быть непосредственным объектом такого нарушения.

Здесь следует также указать на применение понятия «потенциальной жертвы» Европейской комиссией и Судом в делах, где гомосексуалисты в странах, применяюших законодательство, относящее гомосексуальные действия в разряд противозаконных, были признаны потенциальными жертвами ${ }^{37}$. Страсбургские органы признаваги в таких

${ }^{34}$ CM.: Van Dijk P. \& van Hoof G.J.H. Op. cit. - P. 52.

${ }^{35}$ Доклад по делу Campbell and Cosans v. The United Kingdom or 16 мая 1980 г. // Series B: Pleadings, Oral Arguments and Documents (Далее по тексту - «Series B»). - 1985. № 42. - P. 36.

${ }^{36}$ Доклад по делу Campbell and Cosans v. The United Kingdom oт 16 мая 1980 r. // Series B. -1985 . - № 42. - P. 36-37.

${ }^{37}$ Cм. также: Gomien D., Harris D., Zwaak L. Law and Practice of the European Convention on Human Rights and the European Social Charter. - Council of Europe, 1996. - P. 44. 
случаях, что сохранение в силе оспариваемого законодательства являлось вмешательством в право заявителей на уважение частной жизни, поскольку это запрешало гомосексуальные действия, осушествляемые в частной жизни с согласия обоих мужчин. Тот факт, что оспариваемое законодательство не применялось еще к заявителям, не влиял на то, что заявители должны жить в страхе и страдании, поскольку со стороны властей не существовало установленной методики применения данного закона. Следовательно, рассматриваемое законодательство напрямую затрагивало право заявителей на уважение частной жизни вследствие того, что остававшаяся угроза была достаточно реальной ${ }^{38}$.

«Будущая жертва».

В некоторых случаях конвенционные органы признавали, что угроза нанесения ущерба в будущем может быть достаточна для установления статуса жертвы по статье 34 Конвенции. Это возможно в случаях, когда закон или практика еще не применялись к жалующейся стороне, но существует большая вероятность, что государство может сделать это в будущем ${ }^{39}$.

Однако здесь необходимо заметить, что в некоторых случаях Комиссия избегала рассмотрения вопроса о том, можно ли рассматривать заявителя, имеющего определенный интерес в будущем, как жертву. Так, например, в деле, касаюшемся статьи 2 Протокола № 1 («Право на образование»), где сорок матерей жаловались на то, что в результате действия Акта о дошкольном обучении, обнародованного в Швеции 21 декабря 1973 г., они лишились права отправлять своих детей в школы по их выбору. Рассматривая вопрос приемлемости, Комиссия разделила заявителей на три группы. Матери из «первой группы» не могли быть признаны жертвами, поскольку их дети уже прошли дошкольный возраст на момент вступления Акта в силу. «Вторая группа» состояла из матерей, чьи дети не достигли еще дошкольного возраста к тому моменту. В отношении этой группы Комиссия признала, что права и свободы заявителей могут быть нарушены Актом в будущем, однако воздержалась от рассмотрения их жалоб, поскольку в отношении матерей из «третьей группы» было установлено, что их дети уже достигли дошкольного возраста и «могут быть признаны жертвами по

${ }^{38}$ См., например: решение по делу Dudgeon v. The United Kingdom от 22 октября 1981 г. // Series A. - 1982. - № 45; решение по делу Norris v. Ireland oт 26 октября 1986 г. // Series A. - 1989. - № 142.

${ }^{39}$ См.: Gomien D., Harris D., Zwaak L. Op. cit. - P. 44. 
смыслу статьи 25 Конвенции (статья 34 новой редакции Конвенции. Д.К.) для цели настояшей жалобы». Таким образом, Комиссия воздержалась от рассмотрения того, могут ли заявители из «второй группы» быть признаны жертвами или нет ${ }^{40}$.

Тем не менее, анализируя более ранние подобные дела, можно сделать вывод о том, что конвенционные органы все же готовы учитывать «будущий интерес» в определенных случая ${ }^{4 !}$. Подобная ситуация, например, возникла в деле Kirkwood v. The United Kingdom ${ }^{42}$, в котором мужчина жаловался, что его ожидаемая высылка из Соединенного Королевства в Калифорнию (США) являлась бы бесчеловечным и унижаюшим достоинство обращением в нарушение статьи 3 Конвенции («Запрещение пыток»), поскольку он был бы привлечен к ответственности по двум обвинениям в убийстве и одному за попытку убийства и, вероятно, приговорен к смерти. Он аргументировал свою позицию условием выполнения подобного смертного приговора. В частности, он упоминал феномен «камеры смертников», представляющий собой чрезмерную задержку во время апелляционной процедуры, длящейся несколько лет, во время которой он бы содержался под стражей без ясности о результатах апелляции и, следовательно, своей судьбы, что явилось бы бесчеловечным и унижающим достоинство обращением. В отношении признания заявителя жертвой Комиссия решила следующее:«В этих обстоятельствах, оказавшись перед угрозой предстоящего акта исполнительного органа, последствия которого предположительно подвергнут заявителя угрозе обращения по статье 3, Комиссия считает, что заявитель может утверждать, что он является жертвой предполагаемого нарушения статьи $3 \wedge^{43}$.

В нескольких других делах, когда принимались решения о высылке лица в страну, где он предположительно рисковал быть подвергнутым обращению, противоречащему статье 3, конвенционные органы также устанавливали, что лицо, находящееся непосредственно перед угрозой нарушения Конвенции, может жаловаться на то, что оно является жертвой ${ }^{44}$. Если, однако, решение о высылке с территории государства еще не имеет юридической силы, то соответствующее лицо. не

\footnotetext{
40 Жалоба №685774, 40 Mothers v. Sweden // Yearbook. - 1977. - № 20. - P. 236.

4 Van Dijk P. \& van Hoof G.J.H. Op. cit. - P. 54.

42 Жалоба №10479/83, Kirkwood v. The United Kingdom // D\&R. - 1984. - № 37. - P. 158.

${ }^{43}$ Жало6а №10479/83, Kirkwood v. The United Kingdom // D\&R. - 1984. - № 37. - P. 182.

4 См. например: жалоба №17262/90, A. v. France // D\&R. - 1991. - № 68. - P.319; жалоба № 19373/92, Voulfovitch \& Oulianova v. Sweden // D\&R. - 1993. - № 74. - P. 199.
} 
может утверждать, что является жертвой. Только непосредственно уведомление о решении о высьлке, указывающее страну назначения, после исчерпания всех внутренних средств правовой защиты может дать данному лицу статус жертвы. Если же предполагаемый будуший ушерб не может быть еще предвиден, то жалоба признается неприемлемой ${ }^{45}$.

«Косвенная жертва».

При определенных обстоятельствах заявитель, не пострадав напрямую в результате определенного действия или бездействия, может, тем не менее, «косвенным» образом пострадать вследствие нарушения конвенционных прав или свобод другого лица и подать жалобу в Страсбург от своего имени ${ }^{46}$. В этом случае он должен иметь настолько тесную связь с «прямой жертвой» нарушения, что его самого можно было бы признать жертвой. На основании этого страсбургские органы разработали в прецедентном праве концепцию «косвенной жертвы» («Indirect Victim»), подразумевающую, что близкий родственник жертвы либо другая третья сторона может направлять дело в Суд по своей личной инициативе, если данное нарушение наносит (либо также наносит) им ущерб или если у них есть личный интерес прекратить это нарушение $^{47}$. Например, на этом основании было признано, что супруга могла утверждать, что является жертвой предполагаемого нарушения Конвенции, поскольку понесла материальный и моральный ущерб в результате предположительно неправомерно вынесенного в отношении ее мужа приговора, последствиями которого являлись его осуждение, штраф и обязанность возмешения ушерба истцам ${ }^{48}$. Сам по себе нематериальный интерес таюже является достаточным для приемлемости, если «косвенная жертва» при этом становится очевидной. Например, жалоба матери, касающаяся ненадлежащего обращения с содержащимся под стражей сыном, была признана приемлемой ${ }^{49}$. С другой стороны, жалоба заявителя о том, что его сестрам неправомерно было отказано в компенсации за их страдания во время нацистского режима, была признана неприемлемой вследствие того, что он

\footnotetext{
${ }^{45}$ См. например: жалоба №2358/64, X. v. Sweden // Collection of Decisions of the European Commission of Human Rights (Далее по тексту - «Collection»). - 1967. - № 23. - P. 51. th CM.: Leach Ph. Taking a Case to the European Court of Human Rights. - Blackstone Press Ltd, 2001. - P. 73.

${ }^{47}$ См.: жалоба №100/55, X. v. The Federal Republic of Germany // Yearbook. - 1955-1957.

- P. I62-163.

48 Жалоба №1478/62, Y. v. Belgium // Yearbook. - 1963. - № 6. - P. 620.

${ }^{49}$ Жалоба №898/60, Y. v. Austria li Collection. - 1962. - № 8. -- P. 136.
} 
жаловался от своего имени, в то время как компенсация имела отношение только к страданиям сестер, а не его самого и, таким образом, заявитель не мог быть признан жертвой ${ }^{50}$.

Следует заметить, что в определенных случаях Комиссия и Суд квалифицировали владельцев акций компании как жертв предполагаемых нарушений прав данной компании. Но прецедентное право показывает, что конвенционные органы в подобных делах рассматривали владельцев акций не как косвенных, а как прямых жертв ${ }^{51}$. В этих случаях данные лица владели контрольным пакетом акций компании. С другой стороны, в деле Yarrow v. The United Kingdom ${ }^{52}$ Комиссия признала, что индивид, не обладающий контрольным пакетом акций «Компании А», не мог быть признан жертвой вмешательства в право собственности «Компании Б», чьи ценные бумаги принадлежали «Компании А», поскольку обжалуемые меры по национализации «Компании Б» не затрагивали его лично. С точки зрения Комиссии, только «Компания А» могла подать жалобу о нарушении Конвенции. В деле Agrotexim Hellas S.A. v. Greece ${ }^{53}$ было установлено, что вопрос о том, может ли акционер быть признан жертвой мер, предпринятых в отношении компании, не решается исключительно на основании критерия, владел ли он контрольным пакетом акций компании или нет. Комиссия приняла во внимание, что у заявителей была прямая заинтересованность в предмете данного дела, в дополнение к тому факту, что они, как группа, владели контрольным пакетом акций компании. Более того, шел процесс ликвидации компании, и она находилась под специальным режимом эффективного контроля со стороны государства. Соответственно, сама компания не могла подать жалобу против государства. Учитывая особые обстоятельства, Комиссия признала, что заявители (акционеры компании) имели право утверждать, что они являлись жертвами мер, затрагивающих собственность компании, по смыслу статьи 25 Конвенции (статья 34 в новой редакции Конвенции). Следует также привести в качестве примера и дело Wasa Liv Lmsesidigt v. Sweden ${ }^{54}$, где Комиссия решила, что группа лиц - держателей страховых полисов

so Жалоба №1 13/55, X. v. The Federal Republic of Germany // Yearbook - 1955-1957. - P. 162.

${ }^{s 1}$ Жалоба №1 706, X. v. Austria // Yearbook. - 1966. - № 9. - Р. 130; жалоба № 14807/89, Agrotexim Hellas S.A. v. Greece // D\&R. - 1992. - № 72. - P. 155.

s2 Жалоба №9266/81, Yarrow v. The United Kingdom // D\&R. - 1983. - № 30. - P. 155.

${ }^{53}$ Жалоба №14807/89, Agrotexim Hellas S.A. v. Greece // D\&R. - 1972. - № 72. - P. 148.

s4 Жалоба №13013/87, Wasa Liv Ömsesidigt, Försäloingsbolaget Valands Pensionsstiftelse and a Group of Approximately 15000 Individuals v. Sweden // D\&R. -- 1988. - ' 58. - P. 163. 
страховой компании - не может быть признана жертвой, поскольку держатели полисов не обладали каким-либо правом требования в отношении имушества компании. Из вышеизложенного можно сделать вывод, что доктрина «косвенной жертвы» до сих пор еще не разработана с достаточной ясностью в прецедентном праве конвенционных органов в отношении случаев, связанных с обладателями финансового интереса в компаниях.

Предполагаемое нарушение должно все еще сушествовать.

Встречаются дела, в которых обжалуемое предполагаемое нарушение Конвенции уже прекратилось или не сушествует в момент его рассмотрения Судом. Жалоба заявителя в таком случае отклоняется на основании того, что он больше не может утверждать, что является жертвой. Таким образом, если обжалуемое нарушение Конвенции было признано властями государства-ответчика, и заявитель получил компенсацию, то он уже не может требовать признания его жертвой данного нарушения ${ }^{55}$.

Конвенционные органы применяли рассматриваемое правило всегда с учетом обстоятельств конкретного дела. Примером может служить дело, где заявители утверждали, что запись их телефонных разговоров с адвокатами нарушала Конвенцию, но записи к моменту подачи жалобы были уничтожены. Государство-ответчик доказывало, что данное нарушение стало спорным. Комиссия все же решила, что поскольку данное уничтожение не было произведено в ответ на просьбу заявителей и они не получили компенсации, то они все еще могли быть признаны жертвами, несмотря на то, что указанных записей более не существовало $^{56}$.

В делах De Jong, Baljet and Van den Brink v. The Netherlands ${ }^{57}$ и Van Der Sluijs, Zuiderveld and Klappe $v$. The Netherlands ${ }^{58}$ государство-ответчик утверждало в Суде, что заявители не могут быть признаны жертвами нарушения п. 3 статьи 5 («Право на свободу и личную неприкосновенность»), поскольку то время, которое каждый из них провел под стражей в период следствия, было полностью вычтено из меры

${ }^{55}$ CM.: Van Dijk P. \& van Hoof G.J.H. Op. cit. - P. 58-59.

${ }^{56}$ Жалоба №8290/78, A., B., C. and D. v. The Federal Republic of Germany // D\&R. 1980. - № 18. - P. 180.

${ }^{57}$ Pешение по делу De Jong, Baljet and Van den Brink v. The Netherlands or 22 мая 1984 г. // Series A. - 1984. - № 77.

s* Решение по делу Van der Sluijs, Zuiderveld and Klappe v. The Netherlands от 22 мая 1984 r. // Series A. - 1984. - № 78. 
наказания, которая, в конечном счете, была на них наложена. В соответствии с позицией Суда, подобное вычитание не лишает per se по смыслу статьи 25 (статья 34 в новой редакции Конвенции) данного индивида статуса предполагаемой жертвы нарушения п. 3 статьи 5. Суд добавил, что «позиция могла бы быть иной, если бы вычитание из меры наказания основывалось на признании национальными судами нарушения Конвенции $)^{59}$.

Здесь важно отметить, что в делах, где приговоры сокращались заявителям после установления судами фактов о чрезмерных сроках судебных разбирательств в ясно выраженной и соответствующей форме, конвенционные органы признавали, что заявители не могли больше рассматриваться как жертвы нарушения п. 1 статьи 6 Конвенции («Право на справедливое судебное разбирательство») ${ }^{60}$.

Что касается нарушения статьи 3 («Запрещение пыток») Конвенции, то страсбургскими органами в деле East African Asians v. The United Kingdom $^{61}$ было установлено, что, хотя нарушение данной статьи государством-ответчиком в результате недопущения на свою территорию лица по расовому признаку и было прекращено по существу в конченом счете допуском последнего, тем не менее данное лицо не получило компенсации и, соответственно, могло утверждать, что является жертвой.

Представительство заявителя.

Требование о том, что нарушение Конвенции должно нанести ущерб лично заявителю, конечно не препятствует подаче жалобы представителем данного лица. Здесь необходимо отметить, что здесь речь идет о законном представительстве ( LLegal Representation») в ситуациях, когда сама жертва не может (либо не может в полной мере) предпринимать самостоятельно соответствуюшие действия (например, несовершеннолетний, содержащееся под стражей лицо, пациент психиатрической больницы). В подобном случае имя жертвы должно быть известным, и последний, если это возможно, должен дать согласие на подачу жалобы ${ }^{62}$.

${ }^{59}$ Решение по делу De Jong, Baljet and Van den Brink v. The Netherlands or 22 мая 1984 r. // Series A. - 1984. - № 77. - P. 20; решение по делу Van Der Sluijs, Zuiderveld and Klappe v. The Netherlands oт 22 мая 1984 r. // Series A. - 1984. - № 78. - P. 16.

${ }^{60}$ См., например: жалоба №17669/91, Van Laak v. The Netherlands // D\&R. - 1993. № 74. - Р. 158.

${ }^{61}$ Доклад Европейской Комиссии от 14 декабря 1973 г. // D\&R. - 1994. - № 78-A. - P. 5.

${ }^{62}$ См., например: жалоба № 5076/71, X. v. The United Kingdom // Collection. - 1972. № 40 . - P. 66. 
В некоторых делах допускалось представительство лицами, не имеющими на это права по национальному законодательству и, соответственно, не признаваемыми им законными представителями. Однако в случае если представитель не является ни родителем, ни опекуном или попечителем, Суд потребует доказательств полномочий данного лица ${ }^{63}$. Таким образом, родитель, который после развода лишен родительских прав, не может подать жалобу от имени ребенка без доказательства того, что он уполномочен это делать ${ }^{64}$.

В случае смерти жертвы наследник может подать или подлержать уже поданную жалобу только в случае, если предполагаемое нарушенное право относится к собственности, либо если сам наследник по другим основаниям может быть признан жертвой (прямой или косвенной). В деле Kofler v. Italy ${ }^{65}$ Комиссия установила, что наследники умершего заявителя не могли утверждать, «что рассмотрение дела, начатоro de cujus (покойным - лат.), должно быть продолжено Комиссией»). Существо жалобы (она касалась сроков судебных разбирательств, которые закончились осуждением и наказанием заявителя), не допускало того, что она могла быть продолжена наследником, поскольку было тесно связано с личностью покойного заявителя и его наследники «не могли требовать признания за ними достаточного правового интереса для оправдания дальнейшего рассмотрения жалобы от их имени». Комиссия также рассмотрела вопрос о том, может ли быть оправданно дальнейшее рассмотрение дела в случае публичного интереса, и заключила, что «подобная ситуация может возникнуть, в частности, там, где жалоба фактически затрагивает... законодательство, либо правовую систему, пибо практику государства-ответчика». Комиссия признала, что в рассматриваемом деле подобного публичного интереса не было.

Соответственно возникает вопрос о том, могут ли вдова или наследник утверждать, что изначальный интерес заявителя в отношении установления нарушения Конвенции должен быть рассмотрен как интерес, возложенный на них. Подобный интерес был установлен в деле, где еще до своей смерти заявитель жаловался на его осуждение в уголовном порядке. В частности, он утверждал, что не было «справедливого судебного разбирательства» и не была соблюдена «презумпция

${ }^{63}$ CM. также: Clements L.J. European Human Rights. Taking a Case under the Convention. - Sweet \& Maxwell, 1994. - P. 22.

« С., например: жалоба № 8045/77, X. v. Sweden // D\&R. - 1979. - №16. - P. 105.

${ }_{65}$ Жалоба №8261/78, Kofler v. Italy // D\&R. - 1983. - № 30. - P. 5. 
невиновности». Комиссия подчеркнула, что по своей природе жалобы, затрагивающие статью 6 («Право на справедливое судебное разбирательство»), тесным образом связаны с личностью умершего заявителя. Однако было признано, что «эта связь не исключительная и нельзя утверждать, что они (жалобы. - Д.К.) не имеют никакого отношения к вдове». В соответствии с этим вдова была признана жертвой и за ней был оставлен статус заявителя, поскольку обыск жилища, блокировка банковских счетов и наложение залогового ареста на имушество имели прямое влияние на частную жизнь обоих супругов ${ }^{66}$.

В деле $X$. v. France ${ }^{67}$ Суд занял еше более либеральную позицию. Заявитель, которому несколько раз было сделано переливание крови, был заражен СПИДом и вскоре после обращения в Суд скончался, но его родители выразили желание продолжить судебные разбирательства. Суд согласился с тем, чтобы они заняли место заявителя ${ }^{68}$. Кроме того, прецедентное право показывает, что в делах, касающихся сроков разбирательств в национальных органах, Суд обычно признавал, что наследники умершего заявителя могут продолжить начатые им разбирательства по Конвенции ${ }^{69}$.

Необходимо заметить, что если смерть прямой жертвы явилась результатом предполагаемого нарушения Конвенции, например в случае пыток, то родственники данного лица будут, как правило, квалифицироваться как «косвенные жертвы» ${ }^{70}$.

Договаривающиеся Стороны не должны никоим образом препятствовать осуществлению права на индивидуальную жалобу.

В соответствии с последним предложением статьи 34 Конвенции, Договаривающиеся Стороны обязуются никоим образом не препятствовать эффективному осуществлению права на индивидуальную жалобу. Суд, исходя из формулировки данного положения Конвенции, признал, что оно налагает обязанность не препятствовать праву индивида эффективным образом представить жалобу на рассмотрение и вести свое дело в конвенционных органах. Это право, в отличие от прав, содержащихся в Разделе I Конвенции и Протоколах к ней, является процессуальным по природе. Тем не менее, «из самого существа этого

6 Жалоба №10828/84, Funke v. France // D\&R. - 1988. - № 57. - P. 25-26.

${ }^{67}$ Решение по данному делу от 31 марта 1992 г. // Series A. - 1992. - № 234-C.

${ }^{68}$ Решение по делу $X$. v. France or 31 марта 1992 г. // Series A. - 1992. - № 234-C. - P. 89.

${ }^{69}$ См., например: жалоба №14660/89, Prisca and De Santis v. Italy // D\&R. - 1992. № 72 . - P. 147.

${ }^{70}$ Van Dijk P. \& van Hoof G.J.H. Op. cit. - P. 61. 
процессуального права вытекает, что индивидам должна быть предоставлена возможность обжаловать его нарушение». В этом отношении Конвенция должна толковаться как гарантируюшая права, которые могут применяться на практике и являются эффективными, а не просто «теоретическими и иллюзорными»"

Поскольку рассматриваемое право не имеет приостанавливающего эффекта в отношении соответствующих внутригосударственных процедур, Комиссия включила в свои Правила процедуры ${ }^{72}$ положение, которое позволяло ей принимать временные меры. Согласно этому правилу № $36^{73}$, Комиссия могла указать государству-ответчику на временные меры, которые должны приниматься в интересах сторон или для надлежащего рассмотрения дела в конвенционных органах. Следует заметить, что ни Суд, ни Комиссия, полагаясь на добрую волю и сотрудничество Государств-участников, не злоупотребляли этой процедурой, если только не существовала реальная и неизбежная угроза нанесения непоправимого ущерба соответствуюшему лицу ${ }^{74}$. Чаше всего временные меры применяются в делах, связанных с выдачей или высылкой индивида в государство, не являющееся Договаривающейся Стороной, когда сушествует реальная опасность того, что будет нарушена статья 3 Конвенции («Запрещение пыток») $)^{75}$.

В деле Cruz Varas v. Sweden ${ }^{76}$ возник вопрос о том, может ли невыполнение государством-ответчиком временных мер, указанных ему Комиссией в соответствии с правилом №36 Правил процедуры Комиссии (правило №39 (Предварительные судебные меры) новых Правил прочедуры Европейского Суда), быть приравнено к нарушению обязанности не препятствовать эффективному осуществлению права на индивидуальную жалобу. Комиссия решила, что было нарушение данного положения в результате высылки Щвецией заявителя в Чили, поскольку не были приняты во внимание указания Комиссии о том, что в соответствии с правилом № 36 Правил процедуры Комиссии (правило

\footnotetext{
"Pешение по дету Cruz Varas v. Sweden or 20 марта 1991 г. // Series A. - 1991. - № 201. - P. 36.

72 Текст Правил процедуры Европейской комиссин см.: Yearbook. - 1994. - № 33А. P. $140-165$.

${ }^{73}$ В новых Правилах процедуры Европейского суда по правам человека, вступивших в силу I ноября 1998 г., это закреплено в правиле № 39 «Времекные меры».

${ }^{74}$ Reid K. A Practitioner's Guide to the European Convention on Human Rights. - Sweet \& Maxwell, 1998. - P. 14.

${ }^{75}$ Krüger H.C. \& Nørgaard C.A. Op. cit. - P. 668.

${ }^{76}$ Решение по делу от 20 марта 1991 г. // Series A. - 199! . -- № 201.
} 
№ 39 (Предварительные судебные меры) новых Правил процедуры Европейского Суда) высылка должна быть приостановлена на время рассмотрения дела. В этих обстоятельствах Комиссия решила, что высылка заявителя помешала рассмотрению дела и сделала право на жалобу незффективным, хотя позже она и признала, что не было нарушения статьи 3. Суд, тем не менее, занял такую позицию, что Конвенция не содержит положение, уполномочивающее конвенционные органы указывать на временные меры, и, таким образом, вследствие отсутствия специального положения, указание, содержащееся в правиле № 36 (правило № 39 (Предварительные судебные меры) новых Правил процедуры Европейского суда), не имеет обязательной силы. Кроме того, было отмечено, что фактически степень препятствования индивиду со стороны государства была несущественной. По мнению ряда исследователей, это решение Суда вызывает сожаление, и судьи, оказавшиеся в меньшинстве, заняли правильную позицию ${ }^{77}$. По их мнению, защита по Конвенции будет бессмысленной, если государство может выдавать или высылать индивида, не выяснив предварительно в той мере, в какой это возможно, последствия данного действия. Суд неоднократно подчеркивал, что «объект и цель Конвенции как инструмента защиты индивида требуют, чтобы ее положения толковались и применялись таким образом, чтобы сделать ее гарантии практичными и эффективными». Те исследователи, которые не согласны с решением Суда, считают, что указанный принцип должен учитываться и при толковании процессуальных гарантий, содержащихся в Конвенции, применительно к их значению и пределам.

Непрепятствование эффективному осуществлению права на индивидуальную жалобу включает также обязанность не вмешиваться в общение и корреспонденцию заявителя с Судом. В деле Akdivar and Others v. Turkey ${ }^{78}$ Комиссия выразила озабоченность по поводу того, что власти Турции обращались непосредственно к заявителям или к тем лицам, которых они считали таковыми, с вопросами о содержании их жалоб, направленных в Страсбург. Было признано неподобающим для властей обращаться с такими вопросами к заявителям в отсутствие их адвокатов, поскольку «подобные инициативы могут быть интерпретированы как попытки отговорить заявителей от направления жа-

\footnotetext{
${ }^{7}$ Knüger H.C. \& Norgaard C.A. Op. cit. - P. 669; Van Dijk P. \& van Hoof G.J.H. Op. cit. - P. 62.

${ }_{78}$ Решение по делу от 16 сентября 1996 г. // Европейский суд по правам человека. Избранные решения: В 2 т. - М.: Издательство НОРМА, 2000. - Т. 2. - С. 216.
} 
лоб в Страсбург». С учетом этого Комиссия сделала вывод, что власти государства-ответчика препятствовали осуществлению права заявителей на подачу индивидуальных жалоб.

Таким образом, для надлежащего функционирования системы подачи индивидуальных жалоб в соответствии со статьей 34 Конвенции исключительно важно, чтобы заявители или потенциальные заявители могли свободно общаться с Судом, не испытывая давления со стороны властей соответствующего государства-участника с целью заставить их отозвать свои жалобы ${ }^{79}$.

Здесь следует заметить, что на практике у страсбургских органов возникали трудности, связанные с лицами, которые тем или ином образом были лишены свободы. Комиссия и Суд не рассматривали каждый случай наблюдения за почтой лица, находящегося под стражей, адресованной конвенционным органам, как незаконный, хотя и придерживались позиции, что в «соответствии с духом Конвенции» письма должны передаваться нераспечатанными ${ }^{80}$. Как отмечалось в подобных решениях, важно, чтобы контроль за почтой не являлся цензурой и не приводил к чрезмерным задержкам ${ }^{81}$. Более того, необходимо, чтобы Договаривающиеся Стороны не препятствовали возможности заявителей иметь доступ к досье и документам, которые им могут быть необходимы для разбирательств в конвенционных органах. Как отмечалось Комиссией, конфликт со статьей 25 (статья 34 в новой редакции Конвенции) возникает лишь тогда, когда заявитель не может свободно передавать свои жалобы в конвенционные органы «в полной и детальной форме ${ }^{82}$.

Заслуживает внимания и тот факт, что Конвенция не налагает обязательства на Договаривающиеся Стороны информировать соответствующих лиц о возможности подать жалобу в Суд после исчерпания ими всех внутренних средств правовой защиты. Прецедентное право показывает, что такая обязанность не подразумевается из слов «не препятствовать эффективному осуществлению этого права» ${ }^{83}$.

\footnotetext{
${ }^{79}$ См. также: решение по делу Campbell $v$. The United Kingdom от 25 марта 1992 г. // Series A. - 1992. - № 233. - P. 22.

*o Жалоба №1593/62, X. v. Austria // Yearbook. - 1964. - № 7. - P. 166-168.

${ }^{* 1}$ См., например: жалоба № 12395/86, Chester v. The United Kingdom // D\&R. - 1991.№ 68 . - P. 65.

*2 Жалоба №892/60, X. v. The Federal Republic of Germany // Yearbook. -- 1961. - № 4. - P. 258.

* См., например: жалоба № 1877/63, X. v. Austria /" не опубıикована.
} 